\title{
Natural disturbances of the structure of Norway spruce forests in Europe and their impact on the preservation of epixylic lichen diversity: A review
}

\author{
Magdalena Tanona*, Pawel Czarnota \\ Department of Ecology and Environmental Protection, Faculty of Natural Sciences, \\ University of Rzeszów, Zelwerowicza 4 St., 35-601 Rzeszów, Poland \\ *e-mail: magdalena.tanona@gmail.com
}

Received: 13 August 2019 / Accepted: 22 November 2019

\begin{abstract}
The review of current studies on the importance of two main natural disturbances in montane and boreal forests of Europe, dominated by Norway spruce, namely windstorms and the spruce bark beetle outbreaks, for the accumulation of decaying wood in forest ecosystems, shows the relationship between these processes and the creation of habitat diversity for epixylic lichens, especially in the context of the conservation of rare and endangered species. At the same time, this work reveals insufficiency of knowledge on this subject and points to the potential negative effects of removing this substrate in forests under area protection. It also includes recommendations for modern forestry, in which one of the significant goals would be to protect biodiversity.
\end{abstract}

Key words: bark beetle outbreaks, windstorms, lichen protection, decaying wood.

\section{Introduction}

The contemporary tendency of global warming particularly affects boreal and mountain forests with the participation of Norway spruce Picea abies (L.) H. Karst in its entire range. Warmer winters and drier summers improve the condition of its main natural enemy, the spruce bark beetle Ips typographus (L.) (Schebeck et al., 2017), as well as reducing the natural resistance of spruce (Brang et al., 2013; Netherer et al., 2015). Consequently, the spruce stand decay phenomenon takes on a global character (Brang et al., 2013; Hansen et al., 2016; Marini et al., 2017). It does not bypass even the best preserved, lowland ancient woodlands of the Białowieża Forest (E Poland / W Belarus), where the partially planted spruce at the then border of its range is currently experiencing one of the major bark beetle gradations in Europe (Gutowski \& Jaroszewicz, 2016). In the areas of the natural occurrence of Norway spruce, i.e., the boreal zone and montane areas of Europe, one of the most important factors which enable a massive growth of the bark beetle population is, in addition to climate change, severe wind. The foehn wind in the mountains and periodic windstorms in the lowlands break and overturn shallow-rooted spruces on a large scale. These phenomena, although seemingly catastrophic and destructive, are inscribed in the natural dynamics of spruce forests. They shape the heterogenous nature of a forest ecosystem by stand thinning as well as by stimulating the development of the next generation of light-demanding spruce, and by providing valuable organic matter. This is a favorable situation from the point of view of forest biodiversity, i.a. species richness of lichens, among which a significant group represents obligatory or facultative epixyles, inhabiting almost exclusively various types of decaying wood (e.g., Czarnota, 2012; Jüriado et al., 2003; Kumar et al., 2017; Svensson, 2013). Due to the deficiency of this type 
of substrate in managed forests, the possibility of survival of many species of wood-inhabiting lichens is often limited in Europe to small, passively protected fragments of old forests and forests with long ecological continuity, subject to natural decay processes (e.g., Czarnota, 2012; Malíček \& Palice, 2013; Motiejūnaitè et al., 2004).

\section{Disturbances as a part of forest dynamics}

On the basis of Obidziński's synthesis (2001), disturbances in phytocoenosis can be described as temporally and spatially distinctive events that lead to the destruction of vegetation in a given area and thus to the release of resources, which initiate the process of secondary succession. These include disturbances caused by environmental factors such as natural fires, floods, gales, insect outbreaks, snow avalanches or landslides, or they may be caused by human activities such as tree felling, incendiary fires, or melioration treatments. Certain factors may also act synergistically, intensifying the effects or increasing the risk of other disturbances. An example of this is the mass attack of the bark beetle on spruce trees damaged by strong wind. Natural disturbances of ecosystem stability are of a recurring nature, in a longer or shorter time (e.g., Čada et al., 2016; Mitchell, 2013), which makes them the basic driving force of dynamic changes shaping the heterogenous forest structure.

Based on various scales of devastation of the tree layer under the influence of a disturbing factor, Kuuluvainen and Aakala (2011) distinguish four basic types of dynamics in the boreal conifer forests of Fennoscandia, characterized by a different regenerative response of plant communities after the disturbance: 1) "gap dynamics," characterized by a loss of one up to several neighboring trees (area<200 $\mathrm{m}^{2}$ ); 2) "patch dynamics," i.e., dynamics of medium-sized patches $\left.\left(200 \mathrm{~m}^{2}-1 \mathrm{ha}\right) ; 3\right)$ "cohort dynamics" in forests in which low or medium intensity disturbance over a large area ( $>1 \mathrm{ha}$ ) allowed some trees to survive - this results in the development of multilayered stands; 4) "stand-replacing dynamics," i.e., large scale transformations under the influence of strong disturbances, followed by regenerative succession at the stand scale $(>1$ ha) - it results in the development of single-generation forest fragments.

After the disturbances of low and medium intensity occur, there is also a rapid and strong regenerative response of the forest, which is caused, among other things, by reduced competition and the increased availability of light, space and nutrients (Hahn et al., 2007; Szwagrzyk, 2000; Valverde \& Silvertown, 1997). In the case of stand-replacing disturbances, the forest is gradually recreated, although in this case the characteristic, strong incremental response of the trees exposed to the sun is observed (e.g., Metslaid et al., 2007). Similar dynamics are also charac- teristic of natural and scarcely human affected forest communities with the participation of Norway spruce, which is confirmed by dendrochronological analyses carried out, for example, in the forests of the Tatra Mts. (High Carpathians) (Holeksa et al., 2016) and of the Šmava Mts. (Čada et al., 2013). The results of the above-mentioned works indicate that the dynamics of mountain spruce forests in Europe are driven mainly by disturbances of small and medium spatial scale.

\section{Function and meaning of deadwood in the forest - new views, old practices}

The last decades of intensive ecological research conducted in the world in relation to the role of rotting wood in forest ecosystems (e.g., Harmon et al., 1986; Hunter, 1990; Spribille et al., 2008; Wu et al., 2005) have brought a significant shift in views on this resource management system in the forest landscape in the communities of European decision makers and managers. Until recently, dead standing trunks, fallen logs, or branches and stumps left after cutting were seen mainly as a source of tree parasites, flammable material in the litter or a potential threat to forest workers and users. However, the key impact of decaying wood on the shaping of forest biological diversity has been appreciated lately (De Grandpré et al., 2018). Forest resources management which emphasizes the creation and preservation of forest habitats related to deadwood (Humphrey \& Bailey, 2012), also determines the stability and persistence of ecosystems in the perspective of sustainable development policy (Duncker et al., 2012; Kuuluvainen, 2017; Stanturf et al., 2014). Dead tree remnants of various sizes, origins (trunks, branches, roots), and degrees of decomposition provide the substrate, shelter, breeding grounds, and food source for a large amount of forest species in Europe (Berglund \& Jonsson, 2001; Bobiec et al., 2005; Drapeau et al., 2009; Dudley \& Vallauri, 2004; Kulakowski et al., 2017; Svensson, 2013). It is also estimated that there may be up to 1 million species of plants, animals and fungi associated with this substrate in the world (Stokland et al., 2012). This was strongly emphasized, especially during the Fourth Ministerial Conference on the Protection of Forests in Europe (MCPFE), where representatives of the governments of 44 European countries established deadwood as one of the basic indicators of forest biodiversity (Schuck et al., 2004).

Understanding and acceptance of the inviolability of ecological processes for the survival of large number of dependent organisms, especially those with specific habitat requirements are crucial in the modern approach to environmental protection. It is necessary to safeguard areas in which these processes can take place in accordance with the natural order against direct human interference, even 
in the case of catastrophic phenomena. The new approach makes us take into account the naturalness of dieback processes of some trees at various stages of forest stand development as well as the multidimensionality of connections between different groups of forest organisms and their habitats. In a natural forest perceived in such a way, dead trees, even in large quantities, constitute the most important factor enriching species diversity and ensuring the stability of populations and the continuity of ecological processes (Bobiec et al. 2005; Kulakowski et al., 2017; Nagel et al., 2013; Schuck et al., 2004). At the same time, the decaying wood removal practice, as part of sanitary procedures (salvage logging) is still a traditionally accepted form of active protection of valuable forest fragments in Europe and worldwide, even in forest parks and nature reserves (e.g., Grodzki, 2016; Grodzki et al., 2006; Leverkus et al., 2018; Loch et al., 2001; Svoboda et al., 2010). In particular, this applies to the occurrence of cambio- and xylophagous insect gradations, or the threat of gradation alone, as a result of, e.g., the incidence of windfalls over vast areas. Numerous studies indicate indeed that depriving spruce bark beetles of breeding material in the form of damaged trees results in the limiting of the peak population and the shortening of the time of gradation (Grodzki et al., 2006; Hilszczański \& Starzyk, 2017), however, the actions carried out are not able to prevent mass proliferation of these beetles in a highly effective way (Wermelinger, 2004; BIO Intelligence Service, 2011). On the other hand, they result in a number of further negative ecological consequences, among which, apart from habitat loss for many species, one can additionally mention disturbances of the function of the forest as a carbon and water storage reservoir and a source of organic matter, which is necessary, among other things, for the proper condition of the young generation of trees (Irauschek et al., 2017; Lõhmus et al., 2005). Researches conducted in protected forests subjected to natural disasters in Central European national parks suggest that salvage logging adversely affects biodiversity (e.g. Lehnert et al., 2013; Thorn et al., 2014; 2016; 2018) and its reversion (Jonášová \& Prah, 2004; Jonášová \& Matìjková, 2007) mainly by removing the substrate and changing the microclimatic conditions. It is worth quoting here for comparison, some of the related experiences referred to the North American forests: Foster and Orwig (2006), analyzing the effects of preemptive and salvage harvesting after true bug Adelges tsugae Annand outbreaks in forests dominated by eastern hemlock in the New England region, USA, emphasize that the treatments used caused more widespread and harmful changes in the functioning of the ecosystem than the disturbance itself, which was in the form of nitric cycle disruptions, changes in vegetation and soil scarification. Similar negative effects were not observed at that time on unlogged surfaces where the effects of windstorms on the ecosystem were simulated. The authors of the comparison of the most important recent works dealing with the topic of sanitary cuts and their effects on ecosystems (Leverkus et al., 2018), as a criterion for assessing these activities, in addition to those already mentioned, also rise the case of an alteration in forest structure, ecological processes and ecosystem services, as for example the intensity of soil erosion or hydrological regimes.

\section{Natural forest disturbances - diversity of habitats and substrates - diversity of lichens}

The importance of insect outbreaks and severe wind in forest ecosystems in the context of preserving the diversity and abundance of wood-inhabiting lichens is scarcely recognized in the world. With regard to Norway spruce as the host tree, this aspect has recently been taken up at least twice in Central Europe: for the first time in the years 2008-2010 in Czarnota's study (2012) in highmountain spruce and mixed spruce-beech forests in the strict reserves of three Carpathian National Parks - Tatra NP, Gorce NP and Babia Góra NP (S Poland). The analyses concerned with the species composition of epixylic lichen biota on spruces dead due to windstorms or spruce bark beetle outbreaks in those parks confirmed the presence of 231 species of lichens and lichenicolous fungi. This contained the obligatory epixyles (according to the list by Spribille et al., 2008), such as Absconditella lignicola, Chaenotheca brunneola, Elixia flexella, Lecanora sarcopidoides, and Xylographa vitiligo, as well as at least 66 species with different threat status in Poland. This is equivalent to $8.86 \%$ of lichen species specified on the Polish red list of lichens (excluding the extinct species according to Cieśliński et al., 2006), in an area equal to less than $0.06 \%$ of the land surface of the country. These numbers give an idea of the importance of protecting the long-lasting ecological processes in shaping the diversity of habitats that provide survival conditions for many specialized species of lichens.

Similar analyses were conducted by Bässler et al. (2016) in the area of montane spruce forests of the Bavarian Forest NP (SE Germany). The species compositions of lichens and fungi colonizing wood on two types of sites were compared: in forest gaps resulting from the activity of the spruce bark beetle and in dense stands. It was estimated that the species diversity of the first group, that is in open positions, was greater. A seemingly drastic change in microclimatic conditions was only a minimally important factor grouping fungal species in functional terms, while for lichens, it was not a significant habitat filter. Open areas were preferred by species with larger and more complex forms of thallus (lichens; like for example Hypogymnia physodes, H. tubulosa, Parmeliopsis 
ambigua, Platismatia glauca, Pseudevernia furfuracea) and fruiting bodies (fungi).

The latest results showing the impact of salvage logging in areas affected by natural disturbances were presented by an international team of researchers, based on the floristic and faunistic data collected on wind-damaged surfaces in the Šumava forests (Thorn et al., 2016) and again, based on a wide range of literature data from posthurricane, post-bark beetle, and burned stands from various parts of the world (Thorn et al., 2018). In the first paper, the authors presented a simulation of changes in the number of species belonging to 8 systematic groups, 4 of which were directly dependent on deadwood (i.e., epixylic mosses and lichens as well as saproxylic fungi and beetles), as a result of limiting deadwood resources to approximately $15 \%$. In the second work, the species composition was compared within 24 groups of forest organisms, divided into two categories: 1) epi- and saproxyles 2) others, not related to wood as a substrate, in areas of salvage logging and those passively protected. The results of both studies indicate a clear reduction in the number of species inhabiting deadwood (lichens were examined on windthrows) in areas under active protection, although the observations were carried out in a short period of time after the disturbance, usually not exceeding 5 years.

In comparison with scarce research on the significance of natural disturbances such as insect gradations and windstorms in Norway spruce forests for shaping the diversity of lichenized fungi, the literature gives more attention to the relationships of these organisms with decaying wood as a substrate for growth, without inquiring about its genesis. The essence of the majority of these studies was the relationship between the type, amount, and decomposition degree of substrate and the species composition of lichens that inhabit deadwood (Kruys et al., 1999; Nascimbene et al., 2010; Dittrich et al., 2014). The phenomenon of strict specialization, well known in nature, of many species using only a narrow range of ecological niches in the environment was confirmed (Myllys \& Launis, 2018; Santaniello et al., 2017; Svensson et al., 2016).

Usually, snags are the substrate that epixylic lichens occupy most frequently (Holien, 1996; Humphrey et al., 2002; Svensson et al., 2016). This is understandable due to the wide variety of habitats which they offer. In line with the height gradient and the exposure, the humidity and sunshine conditions change, and these in turn determine the speed of wood rotting (Staniaszek-Kik et al., 2019). As a result, snags can be colonized by species with different requirements, e.g., the higher, drier, and harder parts of trunks are more likely to be settled by species in the order Caliciales (e.g. Chaenotheca xyloxena, Calicium glaucellum, C. salicinum, C. trabinellum), crustose representatives of the genus Lecanora (L. subintricata, L. phaeostigma, L. pulicaris), Palicella filamentosa, Strangospora moriformis and non-lichenized Mycocalicium subtile (e.g. Smith et al., 2009; Czarnota, 2012) while the lower ones, with a more decayed, softer wood are often dominated by representatives of the genus Cladonia (Nascimbene et al., 2008b). Lying logs, when compared to standing snags, are characterized by less diverse microhabitats, greater shading, and higher dampness of the substrate. Under these conditions, there is strong competition for the living space with mosses (Nascimbene et al., 2008b), which is the reason for the limiting of the species pool of lichens on this ground. Nevertheless, as habitats with a very large surface, the lying logs and those suspended above the ground give epixylic lichens a very wide range of settling possibilities. The increased rate of decomposition, especially of those trunks whose lower entire surface contacts the ground, accelerates the entry of species dependent on a more decomposed substrate (Humphrey et al., 2002), like some species from the genera Micarea (e.g. M. hedlundii, M. prasina s.1.), Lichenomphalia (L. umbellifera, L. hudsoniana), Placynthiella (P. dasaea, P. icmalea), Trapeliopsis (T. viridescens, T. glaucolepidea), Icmadophila ericetorum or Cladonia (e.g. C. digitata, C. squamulosa) (Smith et al., 2009; Czarnota \& Węgrzyn, 2012; Czarnota, 2012, mat. unpubl.).

Tree stumps are also characterized by very high species diversity (Svensson et al., 2013). Their importance is particularly considered in maintaining the biological diversity of managed forests, as they, together with smaller branches and tree tops (i.e., "slash"), are often the only remains after clear-cuttings, and therefore also the main substrate there for organisms dependent on decaying wood (Caruso et al., 2008; Magnusson, 2010). When examining the species composition of lichens on dead spruce branches in tree tops in cultivated stands of southern Sweden, Caruso et al. (2008) determined that they had richer lichen biota per unit area compared to the stumps of the same tree species, examined simultaneously. Slash were preferred by for example Lecanora carpinea, Ochrolechia androgyna or Platismatia glauca, while stumps in this study were "exclusively" colonized, for example, with Absconditella lignicola, Bacidina chloroticula, Lecanora argentata, L. chlarotera, L. cadubriae and most of the Cladonia species. The recorded number of lichen species was, however, the result of comparing the composition of the biota inhabiting the lateral surface of the branches with the cut and not with the entire surface of the stumps, which could have had a decisive effect on the obtained results. In almost identical field conditions, Svensson et al. (2016) showed that the branches were the least frequent substrate among other types of deadwood (i.e., standing and lying trunks and stumps), which indicates how important it is to keep as large amounts of coarse woody debris (CWD; division by Yan et al., 2006) as possible in managed forests.

The studies distinguishing the use of the root plates of spruce windthrows by lichenized fungi in the Polish part 
of the Western Carpathians were carried out by Czarnota (2012). The results of his observations indicated a great potential significance (equal to that of standing trunks) of this specific habitat in the preservation of lichen species threatened on a country scale, including many epixyles. Among them there were e.g. Absconditella delutula, Agonimia repleta, Micarea myriocarpa, or Psilolechia clavulifera. The evaluations also showed that the great majority of epiphytic lichens observed on the surrounding living trees were able to inhabit both the root system of windthrows and bare wood of dead standing trees, which can be considered an effect of one of the adaptations of the local lichen biota to the repeating, natural disturbances, characteristic to montane spruce forests.

One of habitat parameters important for lichens, which is also frequently reported in the literature, is the age and the associated decomposition degree of the top layers of wood (Caruso et al., 2010; Rudolphi, 2007; Nascimbene et al., 2008a; Söderström, 1988b). While the exposed wood of recently dead trees is colonized mainly by species found on the bark of the surrounding living trees (Nascimbene et al., 2008b), changing habitat conditions, with the progressive decay, gradually contribute to the transformation of the initial epiphytic composition of the lichen biota, through epixylic species, to the epigeic ones (Botting \& DeLong, 2009; Söderström, 1988a). The final stages of decomposition are characterized by partial displacement of lichens under the influence of competitive mosses and higher plants (Kumar et al., 2017).

The species richness of lichens is indirectly determined by the structure of the site, which consists of, among other things, the quantity and quality of the remnants of dead trees, and tree crown cover. Natural, old-growth forests and, to some extent, forests in the early stages of succession (after the occurrence of natural or anthropogenic disturbances) are characterized by the largest resources of decaying wood (Hilmers et al., 2018) and greater access to light (Paltto et al., 2008; Valverde \& Silvertown, 1997), which translates into a greater abundance of woodinhabiting lichens, e.g., in alpine spruce forests studied by Nascimbene and others (2010). The age of the stand and its vertical diversification influenced the richness of lichen species on CWD in the studies carried out by Rheault and others (2009) in boreal spruce and spruce-fir forests. More diverse lichen biota in old mixed forests with welldeveloped undergrowth, according to the authors, was associated, i.a., with better humidity conditions and a greater variety of coarse, decaying wood. Ellis (2013) argues, that the diversity of microhabitats in ecosystems rich in rotting material is an asset allowing for slow adaptation of lichen biota to progressing climate change.

The influence of the stand age on the occurrence and frequency of lichens on deadwood is derived from many species deep attachment to the centuries-long continuity of ecological processes. The presence of the most sensitive species, e.g., Calicium trabinellum, Chaenotheca brachypoda, Ch. brunneola, Ch. chlorella, or Cladonia parasitica, unable to survive in the landscape under severe human pressure, determines the state of preservation of the most valuable fragments of former primeval forests (Motiejūnaite et al., 2004; compare also Selva, 2003). A further issue is related to this, namely the impact of management in forest ecosystems, which must confront the needs of nature conservation and forest management, on the preservation of species diversity of lichen biota, and in particular wood-inhabiting lichens.

Decaying wood resources in commercial spruce forests are definitely small. The reason is not only the distribution of almost all bred trees which have reached a given felling age but also the removal of trees and their fragments withered as a result of activity of fungal pathogens or insect feeding (in Poland, for instance, it is regulated by the Forest Protection Manual, 2012), and the grinding of logging residues, which is done to improve the quality of the soil on the cultivated area or for biofuels (Jakubowski \& Gornowicz, 2014; Rudolphi \& Gustafsson, 2005). As a result of these activities, modest quantities of rotting wood do not constitute sufficiently rich habitat for epixylic lichens, especially those specialized and sensitive to microclimatic changes, which are consequently the essence of regional or national red lists. This is confirmed by numerous analyses conducted in managed and natural forests in Europe, for example in Poland (Kubiak, 2013), Estonia (Lõhmus et al., 2005), Finland (Ylisirniö \& Hallikainen, 2017), Sweden (Rudolphi \& Gustafsson, 2011; Santaniello et al., 2017), Italy (Nascimbene et al., 2013), or Romania (Ardelean et al., 2015). Many centuries of logging activity and modern management systems in commercial forests have led to a significant loss of habitats for lichens as well as to changes and the impoverishment of the species composition of historical lichen biota (Josefsson et al., 2010; Nascimbene \& Marini, 2010).

\section{Conclusion}

This review of recent (mainly European) research dedicated to lichens growing on wood, shows the considerable value of coarse, standing, dead trunks and overturned, rotting logs for preserving their species richness, including regionally and globally rare or endangered species of lichens. In the creation of these habitats, biotic and abiotic factors characterized as natural disturbances, such as spruce bark beetle gradations in boreal and mountain spruce forests, or gales, play an extremely important role. The ecosystem value of natural dynamics of forests should be more appreciated, especially in protected forests designed to preserve the species diversity of the area. Salvage logging in those 
natural forests should be no longer proceeded, due to its negative effect on biological diversity and the forest regeneration, following a catastrophic phenomena. It is necessary to pay more attention on lichenological researches in areas subjected to different types of disturbances and their intensity, to thoroughly understand the role of these phenomena in the preservation of wood dependent lichens.

On the basis of the above-cited and other studies considering the importance of decaying wood in forest ecosystems, the following recommendations can be distinguished in terms of methods of forest management aimed at increasing the biological diversity of forests, including the species diversity of lignicolous lichens, and at increasing the survival chances of protected and endangered species:

1) Leaving larger amounts of decaying wood of different types and decomposition levels in forest (Humphey et al., 2002; Lõhmus et al., 2005; Nascimbene et al., 2013; Ohlson et al., 1997; Svensson et al., 2016);

2) Leaving a certain number of old trees until their natural death and decay (especially in logging areas), as a potential source of deadwood and species refugium in the process of environmental recolonization (Nascimbene et al., 2007; Santaniello, 2017);

3) Applying of logging methods and forest regeneration which imitate the natural dynamics of disturbances (Holien, 1996; Lõhmus et al., 2005; Paltto et al., 2008; Santaniello et al., 2017);

4) Extending the felling age (increasing the size of potential future deadwood (Humphrey et al., 2002) and appreciating the value of the forest as a source of diaspores of species that make up a stable ecosystem (Hilmo et al., 2011; Nascimbene et al., 2007);

5) More frequent use of selective cuttings as a substitute for clearcuttings, aiming at creating more heterogenous habitats (Rudolphi \& Gustafsson, 2011), and ensuring the continuity of ecological processes (Humphrey et al., 2002);

6) Saving a greater number of living, mature trees or their groups in logging areas (shading, shortening the routes for diaspores to the target substrate) (Nascimbene et al., 2007);

7) The determination of special biodiversity zones in highly productive forest fragments (Lõhmus et al., 2005; Svensson et al., 2016);

8) Leaving the most valuable fragments of high quality natural forests through spontaneous ecological processes without human intervention (Lehnert et al., 2013).

\section{Acknowledgements}

We thank to Ms. Anna Sprzęczka for her editorial corrections in English.

\section{References}

Ardelean I. V., Keller Ch. \& Scheidegger Ch., 2015, Effects of management on lichen species richness, ecological traits and community structure in the Rodnei Mountains National Park (Romania). PLoS ONE 10(12): e0145808. (doi: 10.1371/journal.pone.0145808).

Bässler C., Müller J., Cadotte M. W., Heibl C., Bradtka J. H., Thorn S. \& Halbwachs H., 2016, Functional response of lignicolous fungal guilds to bark beetle deforestation. Ecological Indicators 65: 149-160. (doi: 10.1016/j.ecolind.2015.07.008).

Berglund H. \& Jonsson B.G., 2001, Predictability of plant and fungal species richness of old-growth boreal forest islands. Journal of Vegetation Science 12(6): 857-866. (doi:10.2307/3236874).

BIO Intelligence Service, 2011, Disturbances of EU forests caused by biotic agents. Final Report prepared for European Commission (DG ENV), Paris, 273 pp. (https://ec.europa.eu/environment/forests/pdf/FBD_report_2012.pdf), [Accessed: 04.11.2019].

Bobiec A., Gutowski J.M., Zub K., Pawlaczyk P. \& Laudenslayer W.F., 2005, The afterlive of a tree, WWF Poland, Warszawa-Hajnówka, 248 pp. (https:// blogs.helsinki.fi/deadwoodmeeting/files/2016/03/Bobiec@al2005.pdf), [Accessed: 04.11.2019].

Botting R.S. \& DeLong C., 2009, Macrolichen and bryophyte responses to coarse woody debris characteristics in sub-boreal spruce forest. Forest Ecology and Management 258: 85-94. (doi: 10.1016/j.foreco.2009.08.036).

Brang P., Breznikar A., Hanewinkel M., Jandl R. \& Maier B., 2013, Managing Alpine Forests in a Changing Climate, [in:] G.A. Cerbu, M. Hanewinkel, G. Gerosa, R. Jandl (eds.), Management Strategies to Adapt Alpine Space Forests to Climate Change Risks. InTech, New York, USA: 369-383. (doi: 10.5772/56267).

Čada V., Morrissey R.C., Michalová Z., Bače R., Janda P. \& Svoboda M., 2016, Frequent severe natural disturbances and non-equilibrium landscape dynamics shaped the mountain spruce forest in central Europe. Forest Ecology and Management 363: 169-178. (doi: 10.1016/j.foreco.2015.12.023)

Čada V., Svoboda M. \& Janda P., 2013, Dendrochronological reconstruction of the disturbance history and past development of the mountain Norway spruce in the Bohemian Forest, Central Europe. Forest Ecology and Management 295: 59-68. (doi: 10.1016/j.foreco.2012.12.037).

Caruso A., Rudolphi J. \& Thor G., 2008, Lichen species diversity and substrate amounts in young planted boreal forests: A comparison between slash and stumps of $\mathrm{Pi}$ cea abies. Biological Conservation 141: 47-55. (doi: 10.1016/j.biocon.2007.08.021). 
Caruso A., Thor G. \& Snäll T., 2010, Colonization-extinction dynamics of epixylic lichens along a decay gradient in a dynamic landscape. Oikos 119: 1947-1953. (doi: 10.1111/j.1600-0706.2010.18713.x).

Cieśliński S., Czyżewska K. \& Fabiszewski J., 2006, The red list of lichens in Poland, [in:] Z. Mirek, K. Zarzycki, W. Wojewoda \& Z. Szeląg (eds.), The red list of plants and fungi of Poland, Instytut Botaniki im. W. Szafera PAN, Kraków: 71-90 (in Polish). (doi: 10.5586/ mb.2003.001).

Czarnota P. \& Węgrzyn M., 2012, Lichenized and lichenicolous fungi new to Babia Góra National Park (Poland, Western Carpathians). Mycotaxon 122: 89-110.

Czarnota P., 2012, Lichen protection needs natural forest disturbances - examples from some Polish Western Carpathian national parks, [in:] L. Lipnicki (ed.), Lichen protection - protected lichen species. Sonar, Gorzów Wielkopolski: 53-66.

Dittrich S., Jacob M., Bade C., Leuschner Ch. \& Hauck M., 2014, The significance of deadwood for total bryophyte, lichen, and vascular plant diversity in an oldgrowth spruce forest, Plant Ecology 215: 1123-1137. (doi: 10.1007/s11258-014-0371-6).

Drapeau P., Nappi A., Imbeau L. \& Saint-Germain M., 2009, Standing deadwood for keystone bird species in the eastern boreal forest: Managing for snag dynamics. The Forestry Chronicle 85(2): 227-234. (doi: $10.5558 / \mathrm{tfc} 85227-2)$.

Dudley N. \& Vallauri D., 2004, Deadwood - living forests. The importance of veteran trees and deadwood to biodiversity. WWF Raport - October 2004. World Wide Fund for Nature, Gland, Switzerland, 19 pp. (http://www.us.edu.pl/files/wiadomosci/drzewa/Deadwood\%20\%20living\%20forests. $\% 20 W W F 202004$. pdf), [Accessed: 04.11.2019].

Duncker P.S., Barreiro S.M., Hengeveld G.M., Lind T., Mason W.L., Ambrozy S. \& Spiecker H., 2012, Classification of forest management approaches: a new conceptual framework and its applicability to European forestry. Ecology and Society 17(4): 51. (doi: 10.5751/ ES-05262-170451).

Ellis Ch.J., 2013, Risk-based model of climate change threat: hazard, exposure, and vulnerability in the ecology of lichen epiphytes. Botany 91(1): 1-11. (doi: 10.1139/cjb-2012-0171).

Forest Protection Manual, 2012, Vol. I-II, State Forests Information Center, Warsaw: $124 \& 131 \mathrm{pp}$. (in Polish). (http://www.lasy.gov.pl/pl/publikacje/copy_of_gospodarka-lesna/ochrona_lasu/instrukcja-ochrony-lasu), [Accessed: 03.02.2019].

Foster D.R. \& Orwig D.A., 2006, Preemptive and salvage harvesting of New England forests: when doing nothing is a viable alternative, Biological Conservation 20: 959-970. (doi: 10.1111/j.1523-1739.2006.00495.x).
Grodzki W., 2016, Mass outbreaks of the spruce bark beetle Ips typographus in the context of the controversies around the Białowieża Primeval Forest. Forest Research Papers 77(4): 324-331. (doi: 10.1515/frp-20160033).

Grodzki W., Jakuš R., Lajzová E., Sitková Z., Mączka T. \& Škvarenina J., 2006, Effects of intensive versus no management strategies during an outbreak of the bark beetle Ips typographus (L.) (Col.: Curculionidae, Scolytinae) in the Tatra Mts. in Poland and Slovakia. Annals of Forest Science 63: 55-61. (doi: 10.1051/forest:2005097).

Gutowski J.M. \& Jaroszewicz B., 2016, Changes in stands of the Białowieża Primeval Forest in the share of Norway spruce in the context of the spruce bark beetle Ips typographus (L.) population dynamics, [in:] A. Wikło (ed.), The condition of forest ecosystems in the Białowieża Primeval Forest (National Scientific Conference of the Ministry of the Environment and General Directorate of the State Forests, Warsaw, October 28, 2015) State Forests Information Center, Warsaw: 87-108 (in Polish). (https://www.lasy.gov.pl/ pl/publikacje/copy_of_gospodarka-lesna/ochrona_lasu/ stan-ekosystemow-lesnych-puszczy-bialowieskiej), [Accessed: 04.11.2019].

Hahn K., Emborg J., Vesterdal L., Christensen S., Bradshaw R.H.W., Raulund-Rasmussen K. \& Larsen J.B., 2007, Natural Forest Stand Dynamics in Time and Space: Synthesis of Research in Suserup Skov, Denmark and Perspectives for Forest Management. Ecological Bulletins 52: 183-194.

Hansen W.D., Chapin F.S., Naughton H.T., Rupp T.S. \& Verbyla D., 2016, Forest-landscape structure mediates effects of a spruce bark beetle (Dendroctonus rufipennis) outbreak on subsequent likelihood of burning in Alaskan boreal forest. Forest Ecology and Management 369: 38-46. (doi: 10.1016/j.foreco.2016.03.036).

Harmon M.E., Franklin J.F., Swanson F.J., Sollins P., Gegory S.W., Lattin J. D., Anderson N.H., Cline S.P., Aumen N.G., Sedell J.R., Lienkaemper G.W., Cromak K. \& Cummins K.W., 1986, Ecology of coarse woody debris in temperate ecosystems. Advanced Ecology Research 15: 133-302. (doi: 10.1016/S00652504(03)34002-4).

Hilmers T., Frieß N., Bässler C., Heurich M., Brandl R., Pretzsch H., Seidl R. \& Müller J., 2018, Biodiversity along temperate forest succession, Journal of Applied Ecology 55(6): 2756-2766. (doi: 10.1111/13652664.13238)

Hilmo O., Ely-Aastrup H., Hytteborn H. \& Holien H., 2011, Population characteristics of old forest associated epiphytic lichens in Picea abies plantations in the boreal rainforest of Central Norway. Canadian Journal 
of Forest Research 41(9): 1743-1753. (doi: 10.1139/ X11-091).

Hilszczański J. \& Starzyk J. R., 2017, Is it possible and necessary to control European spruce bark beetle Ips typographus (L.) outbreak in the Białowieża Forest? Forest Research Papers 78 (1): 88-92. (doi: 10.1515/ frp-2017-0009).

Holeksa J., Zielonka T., Żywiec M. \& Fleischer P., 2016, Identifying the disturbance history over a large area of larch-spruce mountain forest in Central Europe. Forest Ecology and Management 381: 318-327. (doi: 10.1016/j.foreco.2015.11.031).

Holien H., 1996, Influence of site and stand factors on the distribution of crustose lichens of the Caliciales in a suboceanic spruce forest area in Central Norway. Lichenologist 28(4): 315-330. (doi: 10.1006/ lich.1996.0029).

Humphrey J. \& Bailey S., 2012, Managing Deadwood in Forests and Woodlands: Practice Guide, Forestry Commission, Edinburgh, 32 pp. (https://www.forestresearch.gov.uk/research/managing-deadwood-in-forestsand-woodlands/), [Accessed: 04.11.2019 r.].

Humphrey J.W., Davey S., Peace A.J., Ferris R. \& Harding K., 2002, Lichens and bryophyte communities of planted and semi-natural forests in Britain: the influence of site type, stand structure and deadwood. Biological Conservation 107: 165-180. (doi: 10.1016/S00063207(02)00057-5).

Hunter M.L., 1990, Wildlife, forests and forestry: principles of managing forests for biological diversity. Prentice Hall, Englewood Cliffs, New Jersey, 288 pp.

Irauschek F., Rammer W. \& Lexer M.J., 2017, Evaluating multifunctionality and adaptive capacity of mountain forest management alternatives under climate change in the Eastern Alps. European Journal of Forest Research 136(5-6): 1051-1069. (doi:10.1007/s10342017-1051-6).

Jakubowski J. \& Gornowicz R., 2014, Effects of different methods of soil preparation and utilization of logging residues on the aboveground biomass of 3-year-old pine seedlings. Acta Scientiarum Polonorum Silvarum Colendarum Ratio et Industria Lignaria 13(4): 5-14.

Jonášová M. \& Matìjková I., 2007, Natural regeneration and vegetation changes in wet spruce forests after natural and artificial disturbances, Canadian Journal of Forest Research 37(10): 1907-1914. (doi: 10.1139/ X07-062).

Jonášová M. \& Prah K., 2004, Central-European mountain spruce (Picea abies (L.) Karst.) forests: regeneration of tree species after a bark beetle outbreak, Ecological Engineering 23: 15-27. (doi: 10.1016/j.ecoleng.2004.06.010).

Jonášová M. \& Prah K., 2008, The influence of bark beetles outbreak vs. salvage logging on ground layer vegeta- tion in Central European mountain spruce forests, Biological Conservation 141: 1525-1535. (doi: 10.1016/j. biocon.2008.03.013).

Josefsson T., Olsson J. \& Östlund L., 2010, Linking forest history and conservation efforts: long-term impact of low-intensity timber harvest on forest structure and wood-inhabiting fungi in northern Sweden. Biological Conservation 143: 1803-1811. (doi: 10.1016/j.biocon.2010.04.035).

Jüriado I., Paal J. \& Liira J., 2003, Epiphytic and epixylic lichen species diversity in Estonian natural forests, Biodiversity and Conservation 12: 1587-1607. (doi: 10.1023/A:1023645730446).

Kruys N., Fries C., Jonsson B.G., Lämås T. \& Ståhl G., 1999, Wood-inhabiting cryptogams on dead Norway spruce (Picea abies) trees in managed Swedish boreal forest, Canadian Journal of Forest Research 29: 178186. (doi: 10.1139/x98-191).

Kubiak D., 2013, The significance of old-growth forests in maintaining lichen diversity - an example from the remnants of the Mazovian Forest. Forest Research Papers 74(3): 245-255. (doi: 10.2478/frp-2013-0024).

Kulakowski D., Seidl R., Holeksa J., Kuuluvainen T., Nagel T. A., Panayotov M., Svoboda M., Thorn S., Vacchiano G., Whitlock C., Wohlgemuth T. \& Bebi P., 2017, A walk on the wild side: Disturbance dynamics and the conservation and management of European mountain forest ecosystems. Forest Ecology and Management 388: 120-131. (doi: 10.1016/j.foreco.2016.07.037).

Kumar P., Chen H.Y.H., Thomas S.C. \& Shahi Ch., 2017, Effects of coarse woody debris on plant and lichen species composition in boreal forests. Journal of Vegetation Science 28 (2): 389-400. (doi: 10.1111/ jvs. 12485).

Kuuluvainen T., 2017, Restoration and Ecosystem Management in the Boreal Forest: From Ecological Principles to Tactical Solutions, [in:] S.K. Allison, S.D. Murphy (eds.), Routledge Handbook of Ecological and Environmental Restoration, Routledge, London: 93-112.

Kuuluvainen T. \& Aakala T., 2011, Natural forest dynamics in boreal Fennoscandia: a review and classification, Silva Fennica 45 (5): 823-841. (doi: 10.14214/ sf.73).

Lachat T., Bouget Ch., Bütler R., Müller J., Kraus D. \& Krumm F., 2013, Deadwood: quantitative and qualitative requirements for the conservation of saproxylic biodiversity., [in:] D. Kraus, F. Krumm (eds.), Integrative approaches as an opportunity for the conservation of forest biodiversity. EFI, Freiburg: 92-103.

Lehnert L.W., Bässler C., Brandl R., Burton P.J. \& Müller J., 2013, Conservation value of forests attacked by bark beetles: Highest number of indicator species is found in the early successional stages after bark 
beetle attack, Journal for Nature Conservation 21: 97 104. (doi: 10.1016/j.jnc.2012.11.003).

Leverkus A.B., Benayas J.M.R., Castro J., Boucher D., Brewer S., Collins B.M., Donato D., Fraver S., Kishchuk B.E., Lee E.J., Lindenmayer D.B., Lingua E., Macdonald E., Marzano R., Rhoades Ch.C., Royo A., Thorn S., Wagenbrenner J.W., Waldron K., Wohlgemuth T. \& Gustafsson L., 2018, Salvage logging effects on regulating and supporting ecosystem services a systematic map. Canadian Journal of Forest Research 48(9): 983-1000. (doi: 10.1139/cjfr-2018-0114).

Loch J., Chwistek K., Wężyk P., Małek S. \& Pająk M., 2001. Natural regeneration versus tree planting in the subalpine spruce forest Plagiotecio-Picectum Tatricum of the Gorce National Park (Southern Poland). Nature Conservation 58: 5-15.

Lõhmus A., Lõhmus P., Remm J. \& Vellak K., 2005, Old-growth structural elements in a strict reserve and commercial forest landscape in Estonia. Forest Ecology and Management 216: 201-215. (doi: 10.1016/j. foreco.2005.05.031).

Magnusson H., 2010, Epixylic lichens and bryophytes in young managed forests: substrate preferences and amounts of dead wood. Second cycle, A1E. Dept. of Ecology, SLU, Uppsala, 23 pp. (https://stud.epsilon. slu.se/1682/1/magnusson_h_101101.pdf), [Acessed: 04.11.2019].

Malíček J. \& Palice Z., 2013, Lichens of the virgin forest reserve Žofínský prales (Czech Republic) and surrounding woodlands. Herzogia 26(2): 253-292. (doi: 10.13158/heia.26.2.2013.253)

Marini L., Økland B., Jönnson A.M., Bentz B., Carroll A., Forster B., Grégoire J.C., Hurling R., Nageleisen L.M., Netherer S., Ravn H.P., Weed A. \& Schroeder M., 2017, Climate drivers of bark beetle outbreak dynamics in Norway spruce forests. Ecography 40: 14261435. (doi: 10.1111/ecog.02769).

Metslaid M., Jõgiste K., Nikinmaa E., Moser W. \& Porcar-Castell A., 2007, Tree variables related to growth response and acclimation of advance regeneration of Norway spruce and other coniferous species after release. Forest Ecology and Management 250: 56-63. (doi: 10.1016/j.foreco.2007.03.009).

Mitchell S.J., 2013, Wind as a natural disturbance agent in forests: a synthesis. Forestry: An International Journal of Forest Research 86(2): 147-157. (doi: 10.1093/ forestry/cps058).

Motiejūnaitè J., Czyżewska K. \& Cieśliński S., 2004, Lichens - indicators of old-growth forests in biocentres of Lithuania and North-East Poland. Botanica Lithuanica 10: 59-74.

Myllys L. \& Launis A., 2018, Additions to the diversity of lichens and lichenicolous fungi living on decaying wood in Finland. Graphis Scripta 30(6): 78-87.
Nagel T.A., Zenner E.K. \& Brang P., 2013, Research in old-growth forests and forest reserves: implications for integrated forest management, [in:] D. Kraus, F. Krumm (eds.), Integrative approaches as an opportunity for the conservation of forest biodiversity. EFI, Freiburg: 44-50.

Nascimbene J. \& Marini L., 2010, Oak forest exploitation and black-locust invasion caused severe shifts in epiphytic lichen communities in Northern Italy. Science of the Total Environment 408: 5506-5512. (doi: 10.1016/j.scitotenv.2010.07.056).

Nascimbene J., Dainese M. \& Sitzia T., 2013, Contrasting responses of epiphytic and dead wood-dwelling lichen diversity to forest management abandonment in silver fir mature woodlands. Forest Ecology and Management 289: 325-332. (doi: 10.1016/j.foreco.2012.10.052).

Nascimbene J., Marini L. \& Nimis P.L., 2007, Influence of forest management on epiphytic lichens in a temperate beech forest of northern Italy. Forest Ecology and Management 247(1-3): 43-47. (doi: 10.1016/j.foreco.2007.04.011).

Nascimbene J., Marini L. \& Nimis P.L., 2010, Epiphytic lichen diversity in old-growth and managed Picea abies stands in Alpine spruce forests Forest Ecology and Management 260(5): 603-609.

Nascimbene J., Marini L., Caniglia G. \& Nimis P.L., 2008a, Lichen diversity on stumps in relation to wood decay in subalpine forests of Northern Italy. Biodiversity and Conservation 17(11): 2661-2670. (doi: 10.1007/ s10531-008-9344-1).

Nascimbene J., Marini L., Motta R. \& Nimis P.L., 2008 b. Lichen diversity of coarse woody habitats in a PinusLarix stand in the Italian Alps. Lichenologist 40(2): 153-163. (doi: 10.1017/S0024282908007585).

Netherer S., Matthews B., Katzensteiner K., Blackwell E., Henschke P., Hietz P., Pennerstorfer J., Rosner S., Kikuta S., Schume H. \& Schopf A., 2015, Do waterlimiting conditions predispose Norway spruce to bark beetle attack? The New Phytologist 205(3): 1128-1141. (doi: 10.1111/nph.13166).

Obidziński A., 2001, Disturbance as an element of forest dynamics. Sylwan 145(5): 51-59 (in Polish).

Ohlson M., Soderstrom L., Hornberg G., Zackrisson O. \& Hermansson J., 1997, Habitat qualities versus longterm continuity as determinants of biodiversity in boreal old-growth swamp forests. Biological Conservation 81(3): 221-231. (doi: 10.1016/S0006-3207(97)000 01-3).

Paltto H., Nordén B. \& Götmark F., 2008, Partial cutting as a conservation alternative for oak (Quercus ssp.) forest - response of bryophytes and lichens on dead wood. Forest Ecology and Management 256: 536-547.

Rheault H., Bélanger L., Grondin P., Ouimet R., Hébert Ch. \& Dussault C., 2009, Stand composition and struc- 
ture as indicators of epixylic diversity in old-growth boreal forest. Écoscience 16(2): 183-196.

Rudolphi J., 2007, Bryophytes, lichens and dead wood in young managed boreal forests. Doctoral thesis. Acta Universitatis Agriculturae Sueciae, Uppsala, 32 pp. (https://pub.epsilon.slu.se/1546/1/avhandling nr88_07_kappan.pdf), [Accessed: 04.11.2019].

Rudolphi J. \& Gustafsson L., 2005, Effects of forest-fuel harvesting on the amount of deadwood on clear-cuts. Scandinavian Journal of Forest Research 20(3): 235242.

Rudolphi J. \& Gustafsson L., 2011, Forests Regenerating after Clear-Cutting Function as Habitat for Bryophyte and Lichen Species of Conservation Concern. PLoS ONE 6(4): e18639. (doi: 10.1371/journal. pone.0018639).

Santaniello F., 2017, Impact of tree retention on wood production, biodiversity conservation and carbon stock changes in boreal pine forest. Doctoral thesis. Acta Universitatis Agriculturae Sueciae, Uppsala, 74 pp. (https:// pub.epsilon.slu.se/14574/7/santaniello_f_170921.pdf), [Accessed: 04.11.2019].

Santaniello F., Djupström L.B., Ranius T., Weslien J., Rudolphi J. \& Thor G., 2017, Large proportion of wood dependent lichens in boreal pine forest are confined to old hard wood. Biodiversity Conservation 26: 1295 1310. (doi: 10.1007/s10531-018-1609-8).

Schebeck M., Hansen E. M., SchopfA., Ragland G.J., Stauffer Ch. \& Bentz B.J., 2017, Diapause and overwintering of two spruce bark beetle species. Physiological Entomology 42: 200-210. (doi: 10.1111\%2Fphen.12200).

Schuck A., Meyer P., Menke N., Lier M. \& Lindner M., 2004, Forest biodiversity indicator: dead wood - a proposed approach towards operationalising the MCPFE indicator, [in:] M. Marchetti (ed.), Monitoring and Indicators of Forest Biodiversity in Europe - From Ideas to Operationality. EFI Proceedings, Saarijarvi: 49-77.

Selva S.B., 2003, Using calicioid lichens and fungi to assess ecological continuity in the Acadian Forest Ecoregion of the Canadian Maritimes. The Forestry Chronicle 79: 550-558. (doi: 10.5558/tfc79550-3).

Smith C.W., Aptroot A., Coppins B.J., Fletcher A., Gilbert O.L., James P.W. \& Wolseley P.A. (eds.), 2009, The Lichens of Great Britain and Ireland. British Lichen Society, London, 1047 pp.

Söderström L., 1988a, Sequence of bryophytes and lichens in relation to substrate variables of decaying coniferous wood in Northern Sweden. Nordic Journal of Botany 8(1): 89-97. (doi: 10.1111/j.1756-1051.1988. tb01709.x).

Söderström L., 1988b, The occurrence of epixylic bryophyte and lichen species in an old natural and a managed forest stand in Northeast Sweden. Biological
Conservation 45(3): 169-178. (doi: 10.1016/00063207(88)90137-1).

Spribille T., Thor G., Bunnell F.L., Goward T. \& Björk C.R., 2008, Lichens on dead wood: species-substrate relationships in the epiphytic lichen floras of the Pacific Northwest and Fennoscandia. Ecography 31: 741-750. (doi: 10.1111/j.1600-0587.2008.05503.x).

Staniaszek-Kik M., Chmura D. \& Zarnowiec J., 2019, What factors influence colonization of lichens, liverworts, mosses and vascular plants on snags? Biologia 74(4): 375-384. (doi: 10.2478/s11756-019-00191-5).

Stanturf J.A., Palik B.J. \& Dumroese R.K., 2014, Contemporary forest restoration: a review emphasizing function. Forest Ecology and Management 33: 292-323. (doi: 10.1016/j.foreco.2014.07.029).

Stokland J.N., Siitonen J. \& Jonsson B.G., 2012, Introduction, [in:] J.N. Stokland, J. Siitonen, B.G. Jonsson (eds.), Biodiversity in dead wood. Cambridge University Press, Cambridge: 1-9. (doi: 10.1017/ CBO9781139025843.002).

Svensson M., 2013, Occurrence patterns of dead wood and wood-dependent lichens in managed boreal forest landscapes, Doctoral thesis. Acta Universitatis Agriculturae Sueciae, Uppsala, 50 pp. (https://pub.epsilon. slu.se/10892/1/svensson_m_131112.pdf), [Accessed: 04.11.2019].

Svensson M., Dahlberg A., Ranius T. \& Thor G., 2013, Occurrence patterns of lichens on stumps in young managed forests. PLoS ONE 8(4): e62825. (doi: 10.1371/ journal.pone.0062825).

Svensson M., Johansson V., Dahlberg A., Frisch A., Thor G. \& Ranius T., 2016, The relative importance of stand and dead wood types for wood-dependent lichens in managed boreal forests. Fungal Ecology 20: 166174. (doi: 10.1016/j.funeco.2015.12.010).

Svoboda M., Fraver S., Janda P., Bače R. \& Zenahlikova J., 2010, Natural development and regeneration of a Central European montane spruce forest. Forest Ecology and Management 260: 707-714. (doi: 10.1016/j. foreco.2010.05.027).

Szwagrzyk J., 2000, Large-scale natural disturbances in forest ecosystems: their distribution, character and role in forest dynamics. Wiadomości Ekologiczne 46: 3-19 (in Polish).

Thorn S., Bässler C., Bernhardt-Römermann M., Cadotte M., Heibl Ch., Schäfer H., Seibold S. \& Müller J., 2016, Changes in the dominant assembly mechanism drive species loss caused by declining resources. Ecology Letters 19(2): 163-170. (doi: 10.1111/ele.12548).

Thorn S., Bässler C., Brandl R., Burton P.J., Cahall R., Campbell J.L., Castro J., Choi Ch. Cobb T., Donato D.C., Durska E., Fontaine J.B., Gauthier S., Hebert Ch., Hothorn T., Hutto R.L., Lee E., Leverkus A.B, Lindenmayer D.B., Obrist M.K., Rost J., Seibold S., 
Seidl R., Thom D., Waldron K., Wermelinger B., Winter M.B., Zmihorski M. \& Müller J., 2018, Impacts of salvage logging on biodiversity: A meta-analysis. Journal of Applied Ecology 55(1): 279-289. (doi: 10.1111/1365-2664.12945).

Thorn S., Bässler C., Gottschalk T., Hothorn T., Bussler H., Raffa K. \& Müller J., 2014, New Insights into the Consequences of Post-Windthrow Salvage Logging Revealed by Functional Structure of Saproxylic Beetles Assemblages. PLoS ONE 9(7): e101757. (doi: 10.1371/ journal.pone.0101757).

Valverde T. \& Silvertown J., 1997, Canopy closure rate and Forest structure. Ecology 78(5): 1555-1562. (doi: $10.2307 / 2266148)$.

Wermelinger B., 2004, Ecology and management of the spruce bark beetle Ips typographus - a review of recent research. Forest Ecology and Management 202: 67-82. (doi: 10.1016/j.foreco.2004.07.018).

Wu J., Guan D., Han S., Zhang M. \& Jin Ch., 2005, Ecological Functions of Coarse Woody Debris in Forest Ecosystem. Journal of Forestry Research 16(3): 247252. (doi: 10.1007/BF02856826).

Yan E., Wang X. \& Huang J., 2006, Concept and classification of coarse woody debris in forest ecosystems. Frontiers of Biology in China 1(1): 76-84. (doi: 10.1007/ s11515-005-0019-y).

Ylisirniö A.L. \& Hallikainen V., 2017, Retention patches maintain diversity of epiphytic and epixylic indicator lichens more effectively than solitary trees. Scandinavian Journal of Forest Research 32: 1-12. (doi: 10.1080/02827581.2017.1415370). 